Journal of

Literary Education

\title{
Socio-cultural Positioning of Age Identities in Picturebooks
}

\author{
Posicionamiento sociocultural de las identidades de edad en los \\ libros ilustrados
}

\author{
Posicionament sociocultural de les identitats d'edat als llibres \\ il-lustrats
}

\author{
Johari Imani Murray. Universidad Nacional de Educación a Distancia, España. \\ jmurray2@alumno.uned.es \\ https://orcid.org/0000-0003-4919-0055
}

\begin{abstract}
This study explores literal and metaphorical narrations of age by looking closely at two picturebooks published at the turn of the twenty-first century. The evolutionary Western understanding of the child, childhood and children's literature is briefly periodized as a tension between pragmatic and philosophical concerns. Representations of age are taken to be embedded in socio-cultural positions that implicate historical periods, geographic locations, and economic structures. Ethnicity and gender are similarly discussed as immanent features. Age is presented as much a biological phenomenon as a performative social act of a given culture. The ideas, feelings and events depicted in each picturebook are approached from a structuralist and a postmodernist perspective with the aim of providing a complementary analysis of child representations in alignment with the adult presence, and not necessarily through the lens of aetonomativity. My analysis points to possible applications of the design of age narrations to current and future literacies.
\end{abstract}

Key words: African American, Children's Literature, Picturebooks, Age, Ethnicity, Aetonormativity

\section{Resumen}

Las narraciones literarias y metafóricas de la edad se exploran a través de dos libros ilustrados publicados a principios del siglo XXI. La evolución del entendimiento del niño en el mundo occidental, la infancia y la literatura infantil se muestran con un breve resumen cronológico de la tensión entre las preocupaciones pragmáticas y filosóficas. Se contemplan las representaciones de la edad en posiciones socioculturales que implican períodos históricos, ubicaciones geográficas y estructuras económicas. La etnia y el género se discuten de manera similar como características inmanentes. Se presenta la edad como fenómeno biológico tanto como acto social performativo de la cultura. Las ideas, sentimientos y eventos representados en cada libro se estudian a partir de enfoques estructuralistas y posmodernos con la intención de proporcionar un análisis complementario de las representaciones infantiles en alineación con la presencia adulta sin la necesidad de la condición de la aetonormatividad. Las implicaciones de este 
análisis apuntan a posibles aplicaciones en el diseño de narraciones de edades en trabajos literarios actuales y futuros.

Palabras clave: Afroamericano, Literatura infantil, libros ilustrados, edad, etnia, Aetonormatividad

\section{Resum}

Les narracions literàries i metafòriques de l'edat s'exploren a través de dos llibres il·lustrats publicats a principis del SXXI. L'evolució de l'enteniment de l'infant al món occidental, la infantesa i la literatura infantil es mostren amb un breu resum cronològic de la tensió entre les preocupacions pragmàtiques i filosòfiques. Es contemplen les representacions de l'edat en posicions socioculturals que impliquen períodes històrics, ubicacions geogràfiques i estructures econòmiques. L'ètnia i el gènere es discuteixen de manera similar com a característiques immanents. Es presenta l'edat com a fenomen biològic tant com acte social performatiu de la cultura. Les idees, sentiments i esdeveniments representats en cada llibre s'estudien a partir d'enfocaments estructuralistes i postmoderns amb la intenció de proporcionar una anàlisi complementària de les representacions infantils en alineació amb la presència adulta sense la necessitat de la condició d'aetonormativitat. Les implicacions d'aquesta anàlisi apunten a possibles implicacions en el disseny de narracions d'edats en treballs literaris actuals i futurs.

Paraules clau: Afroamericà, Literatura infantil, Llibres il-lustrats, Edat, Etnicitat, Aetonormativitat

\section{Introduction}

Contemporary society constantly produces age narratives that reverberate in multiple interpretations in which ethnicity and gender are also tied to socio-cultural positionings. In doing so, some of these literal, metaphorical and intertextual interpretations foster economic activities involving experiences, goods and services. Looking at age narration offers an opportunity to gain fresh insights into the ways it may be codified and commodified in literature. Pervasive messages of when, how and where to behave according to age can be noticed readily in works of children's literature. Picturebooks are one example of a commodity that positions age, ethnicity and gender in social and cultural terms within and outside a given narrative.

This paper discusses ways in which age narration, of the child specifically, can be understood in two picturebooks. Katharine Jones (2006) notes that, “The terms 'age role,' 'age difference,' and 'ageuation' point to a cultural process, namely the age-role process ... as well as to the biological process of ageing" (p. 297). However, before those narrations of age are explored, a brief historical 
review of how a child was socially conceptualized in the past and what it is currently known to be, is included as a functional layering of the complex and prevailing notions of "the child." Once established, these fundamental ideas are challenged and assumptions of how ethnicity and gender might be plotted along the coordinates of age and activity are introduced. From this perspective, the varied performative realities of age throughout the lifespan complicate essentialist definitions of child and adult, whilst the adolescent remains a liminal figure. It is through the lens of this childadult tension that each picturebook is analyzed, using first a structuralist interpretation based on the developmental stages widely documented in research studies by psychologists Piaget, Freud, Erikson and Vygotski. Then, critical content analysis is employed along with close reading and contextualization. Mitzi Myers (1988) adroitly defines the nature of this kind of endeavor pointing out that

\begin{abstract}
A New Historicism of children's literature would integrate text and socio-historic context, demonstrating on the one hand how extraliterary cultural formations shape literary discourse and on the other how literary practices are actions that make things happen by shaping the psychic and moral consciousness of young readers but also by performing many more diverse kinds of cultural work, from satisfying authorial fantasies to legitimating or subverting dominant class and gender ideologies, from meditating social inequalities to propagandizing for causes, from popularizing new knowledges and discoveries to addressing life issues like slavery and the condition of the working class (p. 42).
\end{abstract}

Historical overlaying of socio-cultural contexts and generalizations about the child and childhood may be complemented with data derived from digital humanities when applied to children's literature. In this way, qualitative and quantitative analysis work in tandem with socio-cultural contexts of ethnicity and gender themes to highlight ways in which age is presented in selected texts. People are aged by culture (Gullette 1995) while suspended in their interconnecting webs of significance (Geertz 1975). The process of interactivity and interdependence among people at different life stages, as well as with diverse ethnic and gender identities create meaning within and around texts. Children's picturebooks construct age identities through social and cultural positioning, reflective of historical periods, geographic locations, and the ways they do so are embedded in economic structures. 
In this sense, it is important and necessary to make traditionally underrepresented groups visible in and around discussions about representation in children's books in practice as well as in theory. As

\section{The process of interactivity} and interdependence among people at different life stages, as well as with diverse ethnic and gender identities create meaning within and around texts. Children's picturebooks construct age identities through social and cultural positioning, reflective of historical periods, geographic locations, and the ways they do so are embedded in economic structures

a former teacher, educational entrepreneur, and current children's literature researcher, I am aware of and have access to children's books involving characters from diverse backgrounds. I participated in different purchasing programs designed especially for educators to build diversity selection among book choices for students. For me, this is a lifelong skill that always needs to be refined as time and demographics change. In order to promote selection skills for diverse books in students, diverse books must first be available to them. I have actively sought out and made significant personal investments in children's and youths' books and I am a frequent user of public libraries. It is from this interactive relationship with children's literature built along the years that I was able to select picturebooks that showcased children from traditionally underrepresented groups. García-González and Mínguez-López (under review) reminds the critical reader that "Picturebooks appear to have a great potential to narrate diversities as "becomings" rather than as fixed and stable social identities." Each picturebook consumed by a child and adult (listener, reader, user and beholder) holds an iteration of ideas, feelings and events (Arizpe, Bagelmann, Colomer, Martínez-Roldán 2014). The purpose of this study is to look into how age is narrated in picturebooks, explore and justify the possible connotations found in their intertextual manifestations and explain why these representations and what they stand for are important. I intentionally evade the polarization of power along age narrations in my analysis and gesture toward shared, intergenerational, dynamic interdependence in and around the narratives. Please, Baby, Please (2002) by celebrity Spike Lee and Tonya Lewis Lee, illustrated by renowned Kadir Nelson, and Busy Toes (1998) by C.W. Bowie, illustrated by Fred Willingham, are the two picturebooks used to explore the ways in which age is narrated to create social and cultural positionings. 


\section{Theoretical Framework}

Kira Mahamud-Angulo (2020) advocates the application of multimodal and interdisciplinary methods for text analysis similar in spirit to the postmethod perspective Kumaravadivelu (2003) proposes in the context of English language teaching ${ }^{1}$. Combined methods of structuralist interpretation, critical content analysis, close reading and contextualization are employed in my study within the general theoretical framework of New Historicism. Before we begin the analysis of how the child is represented in the literary text, we must take a step back to review our own understanding and perspectives of the child, childhood and its literary representations.

Western culture has evolved in its understanding of the child, childhood and children's literature. Colin Mills (Hunt and Ray 2005) sums up ongoing tensions on the polarizing debates of child, childhood and children's literature as dichotomous oppositions involving exploitation and protection, exposure and censure, entertainment and education, and fantasy and reality (p. 377). Mitzi Myers (1988) proposes that understandings of the 'child', 'childhood' and 'children's literature' are culturally contingent, rather than empirically essentialist, and that they embody the social construction of a particular historical context;" (p. 42).

However, the first Western voice to emerge regarding the child and childhood was Philippe Ariès in Centuries of Childhood (1972). Harry Hendrick (1992) criticized the famous French childhood historian as having

initiated the debate [...] that 'in medieval society the idea of childhood did not exist' [...]. In the sixteenth century, he continues, adults were beginning to see children as a 'source of amusement and relaxation', but not until the seventeenth century did the difference between the two ages begin to be appreciated. By the mid-eighteenth century a modern concept had emerged with the child occupying a central place in the family. (p.1)

The criticism Hendrick voiced concerned especially the historian's use of sources:

\footnotetext{
${ }^{1}$ In the 1990s, Kumaravadivelu presented the idea of postmethod as taking reasonable theoretical and pedagogic risks to move beyond the confines of singular or dualistic methodological approaches to teaching English. He proposed instead that each teaching context is unique as are students and learning goals. Therefore, the methods a teacher applies must be appropriate to the given reality. Kumaravadivelu insisted that academic theory and professional practicality must work in harmony. Simply put, Kamaravadivelu believed that one must use "situation-specific ideas within a general framework that makes sense in terms of current pedagogical and theoretical knowledge." (1992, p. 41)
} 
his [Ariès'] data are [...] unrepresentative [...], takes evidence out of context, confuses prescription with practice, and uses atypical examples. [...] implicitly denies the immutability of the special needs of children, for food, clothing, shelter, affection and conversation [...] saying little of economic and political factors. (p. 1)

Ariès' vision is not incompatible with Karen Coats' historization of childhood provided in the first chapter of The Bloomsbury Introduction to Children's and Young Adult Literature (2017). However, Ariès' summary is comparatively incomplete and does not include historically disenfranchised children. Coats' chronology, on the other hand does include mention of disenfranchised children and their needs. She points to the fact that children in the past were viewed as miniature adults who needed to mature as quickly as possible (p. 14-17). Yet, moving in sync with the development and spread of Judaism, Islam and Christianity, religious ideas influenced how children were seen and thus became regarded as "gifts from God" (Stearns 2006, p. 35). The flip side of this idea held that children were born with the taint of original sin and needed to develop self-control to orient properly their moral compass. The Protestant Reformation cultivated the need for children to become self-aware and repentant (Coats 2017 p. 17-21). These understandings lasted until around the Enlightenment when the French philosopher, Rousseau, and others argued that children were blank slates, "tabula rasa", neither good nor bad, but influenced by society. Following this belief, it can be easily observed how Western society moved towards the idea that children need protection. The Romantics' reaction against the long-standing pragmatics of reason and the restrictions of religions play into the inspired and enduring idea that children hold the hope of the future. It is the belief in the yet-to-be-known that children become symbolic vessels of sentiment and imagination (p. 25). Informed by "discourses of psychology, child development, educational theory, psychoanalysis and social policy," the current understanding of the child is multifaceted (Mills p. 378). Children are a diverse and unique group of individuals with various abilities, experiences and temperaments (Coats 2017 p. 34-37). Childhood is established as a life stage fundamentally distinct from adolescence and adulthood (p. 7-46, 49-80).

Vanessa Joosen moves away from a historical understanding of the child and childhood by offering a metaphorical perspective. In the first chapter of her book Connecting Childhood and Old Age in Popular Media (2018), she cites the 1980s work of Lakoff and Johnson's Metaphors We Live By and their explanation of root metaphors. A root metaphor, according to Lakoff and Johnson, is a 
narrative structure, linking two concepts with shared entailments, complex coherences ${ }^{2}$ and gestalts. Joosen argues that age is not a biological given, but rather a social performance, that is negotiated and narrated by culture, much in the way Judith Butler argues about gender performativity (1988). Margaret Morganroth Gullette (2004), is often credited with the phrase "aged by culture." Given this paradigm, childhood and old age can be treated as a root metaphor. Children are like old people and vice versa. In Joosen's words, media narratives ascribe interchangeable traits between the young and the old. She explains how the relational concepts of age need to take into account the "historical, international, and intermedial context" (p. 12). So, in studying the relationships and stories among different life stages in conjunction with their capitalist implications, she establishes three basic patterns of interaction: affinity, complementarity and conflict. The pattern of interaction based on conflict, as it will be shown in my paper, can be traced in one of the two picturebooks that comprise my sample while the other is based on affinity. In addition, one must keep in mind that the implied audience of a book affects the representation of youth and senescence. The interdependence among people from other stages of life creates meaning. The picturebooks used to support the nuanced and overt dimensionalities of child-adult relationships are different from, yet similar to how Joosen uses Safran Foer's YA novel, Extremely Loud and Incredibly Close (2005). In (2002), the main character's age identity is narrated through a series of situational reprimands. The voice of the adult directed toward the child establishes an age margin, but cunningly enough, the metanarrative, prefaced in the title of the book and repeated throughout, creates additional age margins for some consumers. On the other hand, Busy Toes (1998) is a series of affirmations of what children can do, specifically with their toes from the hidden observing adult and creates a quieter age margin. This hidden narrating adult does not intervene in the activities of the children. The physical agency of the children, although focused on their toes, encompasses a wide variety of play and learning activities. The metanarrative surrounding toes is quite complex and easily associated with Freudian understandings of development and thus marking various age categories. Anita Wohlmann in Aged Young Adults: Age Readings of Contemporary American Novels and Films (2014) insists that age is a metaphorical practice and as

\footnotetext{
2 Lakoff and Johnson (1980) explain a series of conditions for metaphorical concepts to function successfully. Among these conditions, "The most fundamental values in a culture will be coherent with the metaphorical structure of the most fundamental concepts in a culture." (p. 22) In the case of complex coherences across metaphors, they clarify that purpose and overlaying purposes of corresponding metaphorical structures signal direct connections that are contingent upon the integrity of their content. See chapter 17 for a more detailed discussion.
} 
such has metaphorical functions which revolve around norms, ideals and expectations. In this case, later-in-age as in earlier-in- age, bodily awareness, functions and ability gain interest and priority.

Following the work of Umberto Eco, Charles Sutherland in his contribution to Understanding Children's Literature (2009, p. 43) explains how a plurality of codes leads to a plurality of understandings. Assuming all productions are in some way ideological, three things can happen. One, readers of a text can assume or subsume those worldviews. Secondly, readers can import their own beliefs or ignore those presented. Lastly, readers can question the text. These are important considerations because as Joosen (2018) cautions, messages about age are powerful and can influence a person's performative age identity - in other words, how people act their age. Wohlmann (2014) suggests a possible relation among young people and age awareness with their age identities being learned and internalized. Nelson and Fivush (2004) establish the emergence of autobiographical memory gradually across pre-school years in the context of socio-cultural development theory. From this perspective,

Three critical arguments underlie this theory: (a) There is a gradual emergence of autobiographical memory across the pre-school years rather than a point before which there are no auto-biographical memories and after which there are; (b) language is a fundamental social cultural tool in the development of an autobiographical memory system; and (c) there are cultural, gender, and individual differences in autobiographical memory across the life span that need to be explained. (p. 489)

Similarly, Dan McAdams (2008) investigates the internalized and ever evolving story of the self in adults. However, according to his research, the narrative identity does not coalesce until late adolescence and into adulthood (p. 242). From this perspective, age narratives for children in everyday life, as in picturebooks are not autogenerative, but are crafted and imposed by adults and adult narrators. According to the long-standing nature and nurture debate among psychologists, the expected behaviors for individuals based on their age are in part biological and in part socio-cultural (McAdams 1994, pp. 179-191, 293-295, 300-308, 353-359,798). A person's age and the enactment of age place a person not only culturally, socially, geographically but also economically.

The depiction of the child and childhood in children's literature is highly conditioned. In discussing hybridity with regard to this tension on the age spectrum between adults and children, David Rudd (2004) argues that 
The shift in emphasis that I am suggesting parallels the response that Homi Bhabha (1994) made to Edward Said's work on colonialism. In children's literature, Rose herself uses the notion of the child as a colonised being to capture the way that children's literature is imposed on the young reader, seeking to secure him or her. Perry Nodelman (1992) has also noted the parallels, showing how readily 'the child' can be substituted for 'the orient' in Said's Orientalism (1978). However, Bhabha gives Said's work a more psychoanalytical emphasis, suggesting that the relation between coloniser and colonised is less secure, in that the former is always troubled by the relation between the two. (chapter I, para. 2, n.p.)

The dominant expected behaviors and activities for children in Western children's literature are different and separate from the expected behaviors and A person's age and the enactment of age place a person not only culturally, socially, activities of adults (liminal adolescents are pressured to choose or be chosen for). The dominant, modern Western aspiration or idealization of the child and childhood centers on revisiting the traditional geographically but also economically. The depiction of the child and childhood in children's literature is highly conditioned. dichotomies of play and education, protection and love, immediate priorities and long-term resources for all children. The Geneva eclaration of the Rights of the Child, drafted in 1924 by the League of Nations, adopted by the United Nations and consequently revised, evolved into the 1989

Yet, those beautiful ideals, so readily consumed and propagated in many popular works of children's literature become standardized as the normal child, experiencing a normal childhood in a normal context. The child spouse, the child soldier, the child laborer are some examples that run contrary to this norm. Their expected behaviors, activities and experiences do not match their age: adults marry, adults fight in wars, adults toil and labor
Convention on the Rights of the Child advocating that children be "brought up in the spirit of the ideals proclaimed in the Charter of the United Nations, and in particular in the spirit of peace, dignity, tolerance, freedom, equality and solidarity." (para. 7) Yet, those beautiful ideals, so readily consumed and propagated in many popular works of children's literature become standardized as the normal child, experiencing a normal childhood in a normal context. The child spouse, the child soldier, the child laborer are some examples that run contrary to this norm. Their expected behaviors,

activities and experiences do not match their age: adults marry, adults fight in wars, adults toil and 
labor. Trabajar no es un juego (Rivas 1997) is an anthology of various types of works that address the exploitation of child labor. Oh Lord, I Wish I was a Buzzard (Greenberg and Aliki 2002) is based on the real childhood experiences of Gladys Henton working in a cotton field. Children's picturebooks such as ¿Por que estas triste? (2000) by Violeta Monreal and Nuestros Derechos (2003) by Maria João Carvalho, illustrated by Carla Nazareth, in the words of Clémentine Beauvais (Keyes and McGillicuddy 2014), “...can be seen as equipping the child with both the responsibility for the world and the resulting anguish to witness its limitations. Pedagogically speaking, it is, of course, an undeniably paradoxical position, ..." (p. 22).

\section{Methods and materials}

The selection of the two picturebooks used in my study was based on five variables: availability, different representations of age, structure of the book, closeness in publication years and representations of African Americans. One of the concerns voiced by modern socially responsive groups such as World of Words $(\text { WOW })^{3}$, We Need Diverse Books ${ }^{4}$, Inclusive Minds, and \#OwnVoices ${ }^{5}$ is the availability of books involving characters from diverse backgrounds. Underrepresentation of different people as protagonists as compared to the demographics in the United States raises concerns. Carmen Martínez-Roldán (2017) explains how ethnicity and gender of protagonists largely continue to be skewed in the United States as per statistics provided by The Cooperative Children's Book Center $(C C B C)^{6}$ (p. 64).

Busy Toes (1998) and Please, Baby, Please (2002) involve story characters of different ages. Gender performance of the child characters is circumvented in both picturebooks and adult characters are almost absent. Both books maintain a list structure in terms of narrative style and a highly

\footnotetext{
3 "Worlds of Words [WOW] is committed to providing a range of resources to encourage educators at all levels to integrate global literature into the lives of children." (https://wowlit.org/about/)

4 "We Need Diverse Books ${ }^{\mathrm{TM}}$ is a 501(c)(3) non-profit and a grassroots organization of children's book lovers that advocates essential changes in the publishing industry. [Their] aim is to help produce and promote literature that reflects and honors the lives of all young people." (https://diversebooks.org/about-wndb/)

5 \# Ownvoices is a movement started in 2015 online through Twitter by Corinne Duyvis, to advocate for "... kidlit about diverse characters written by authors from that same diverse group."

(https://twitter.com/corinneduyvis/status/640584099208503296)

${ }^{6}$ The CCBC has documented publishing statistics on children's and young adults' books about people of color and First/Native Nations, and by people of color and First/Native Nations authors and illustrators since 1985.
} 
predictable, repetitive discourse. Busy Toes offers a list of descriptors for different kinds of toes while Please, Baby, Please offers a list of reprimands and directives punctuated by a final question at the end of the story. The narrative in Busy Toes evokes different moments throughout a day in which children can engage in different activities with their toes. One of the last illustrations shows three sets of toes cuddling. The final scene reads, "Goodnight toes," with an illustration showing two pairs of feet, drawn in muted tones, in which the toes are visually centered. Please, Baby, Please, provides a very similar narrative with the difference of following one child through her or his day realizing various activities. One of the last illustrations shows the mother tucking in her child after a long day full of action. The final scene ends with the mother kissing her child goodnight. Narrative closure with a goodnight scene is usually employed as an end form in picturebooks as reading before bedtime has become a common practice between a caretaker and a child before going to sleep. Both picturebooks include positive representations of African American characters.

With close readings, the units of analysis were interplayed between text and theory while connecting to how socio-cultural positioning of age identities in picturebooks is used as an indicator of the expectations of how people should act, interact and react based on their age. This study considers two ways in which the analysis of these picture books may be performed. On the one hand, a structuralist's approach is deployed to determine literary archetypes and to ascribe psychological insights to the story's characters and its participants (author, reader, listener, beholder). On the other hand, a postmodern approach to critically question the literary and nonliterary discourses, intertextualities and representations within and around the story books can be applied. Using both sets of tools holds value in what cultural anthropologist Clifford Geertz (1975) called types of subjective self-spun "webs of significance." With this understanding, Justyna DeszczTryhubczak's (2016) warning to be cautious in one's enthusiasm to "idealize the potential of radical literary texts to empower young readers" (p. 216) and Karen Coats' (2018) warning to be cautious in "unconscious bias, masked as objectivity, [...] aris[ing] when we assume that all literary traditions have the same values, objectives and structures," (p.92) underscore how critical scholars need to be careful when questioning textual representations.

\section{Analysis}

Please, Baby, Please (2002) is a story about a middle-class, urban toddler and her or his relationship with the non-specified adult narrator. The gender of the child is not clearly established. Age identity is narrated by means of situational illustrations of the child along with matching reprimands from 
the insinuated parent. The relationship pattern between the adult and child characters is that of conflict. It is not until the end of the story where there is an example of affinity and subversion of the power dynamic. From a structuralist approach, the child character is used as the source of the story to gain psychological insight. David Rudd (Nel and Paul 2011) observes that, “..., a child thinks in 'preoperational' terms (as Piaget argues was common before age seven), then it should appreciate characters in books who do the same." Yet, these kinds of books tend to be more popular and appreciated among adults than among children. (p. 216) Recalling Erik Erikson's eight stages of development (Erikson 1995), one must keep in mind, that "each of these growth crises give rise to certain imaginative themes or motifs that show up in cultural myths and stories..." (Coats 2017, pp. 53). More specifically, the reader can see all of the child's actions in this story coincide with stage two (between the ages of eighteen months and three years old when the child experiences the tension between autonomy versus doubt and shame being played out). In the illustration of the child eating sand with a shovel from the city's communal sandbox, the Freudian theory of development might point to a possible regression to the oral stage. Returning to the Piagetian model, in a following illustration, while there is a clear understanding of sensorimotor skills as the child uses her or his body to protest and resist leaving the playgroup, in another illustration, object permanence may still be in the process of development as the reader can observe the child character about to hide a possibly dirty diaper in the toy bin thus from the child's perspective the diaper will "magically disappear."
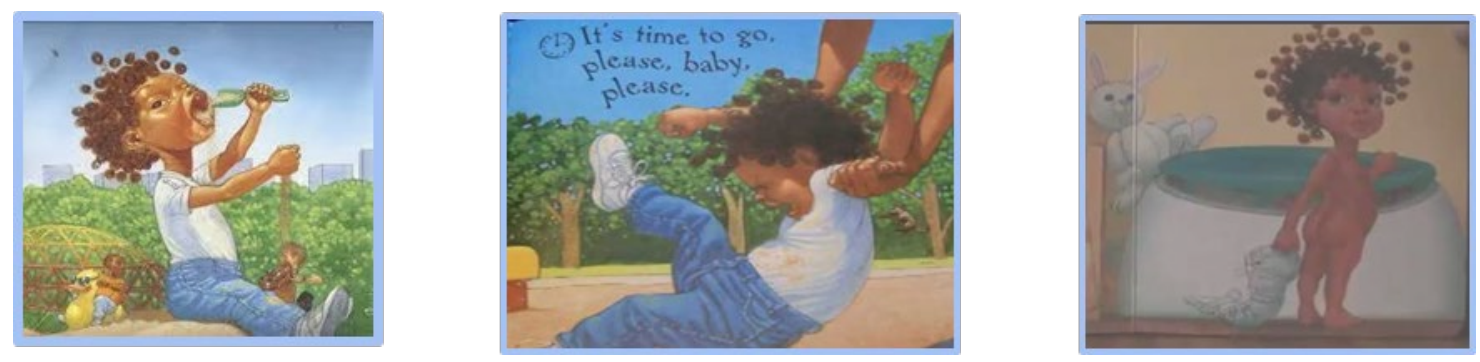

Fig. 1. Please, Baby, Please

In reading the series of these relatively relatable experiences, one option is to engage in the humor of these quotidian situations, at the same time acknowledging that the child character is learning through these rich experiences of trial and error, navigating known and unknown systems of knowledge mediated by the adult. Vygotsky (1978) identifies this cognitive process as a zone of 
proximal development in which the adult engages the child as the child engages her or his environment and the adult provides necessary feedback to support the child's development. But what can these depicted situations tell the reader about the adult or adults or about the culture, society and geographic location in which this story occurs? Louis Rosenblatt's (1978) readerresponse framework, allows the reader-scholar to immerse herself in the critical content analysis to arrive at a socio-cultural positioning of age identities. Starting with the child protagonist again, the researcher asks: Who is she or he? Where is she? When does this story take place? What underlying grammar about age does this story construct?

When I look at this picture book, I see a middle class, African American toddler from a two-parent, heteronormative home, in a turn-of-the-21st-century urban setting, habituating an intertextual fiction that alludes to lines spoken by a character from the 1986 film She's Gotta Have It by famed Brooklyn-born-and-raised, African American film director, Spike Lee. In 2002, of the 3,150 children's books the Cooperative Children's Book Center received, less than 170 were about African Americans and less than 70 were written by African Americans. In 2020, Kadir Nelson, the illustrator of Please Baby, Please, added several more awards, accolades and prestigious commissions to his already acclaimed repertoire of depicting positive images of African American characters in children's books. Yet, in 1963, The Snowy Day by Ezra Jack Keats was the first picture book centering an African American child protagonist without negative stereotyping. Culturally and socially, this work forms part of a significantly bigger conversation about African American identities, place making and history making in the United States. Readers are offered a depiction of an economically comfortable African American family that reflects a basic caring parent-child narrative. In addition, there is a reasonable social and economic interpretation of the illustrations based on a disposable income indirectly shown to actively participate in the current consumer culture. Ushered into the 20th century by the great African American migrations from the rural South to the urban North and after the two World Wars, toys, books, child-specific commodities such as clothes, videos, furniture, disposable food and excess water usage became readily used, expected and available to middle class families. The established age identity of the child-character within this "web of significance" and knowledge coincides with that of the structuralists. The age identity of the adult character comes into being through the performative dimension of the authorial voice of narrated imperatives of dos and don'ts. But these understandings also can extend to the intertextual performance of the litany of pleas, "Please, baby, please," that implicate an older version of the fictional character, Mars Blackmon, from the aforementioned film. Mars Blackmon character's catchphrase, "Please, baby, 
please," is used throughout the film She's Gotta Have It (1986) and may be an indicator that he is the child's father and adult narrator, especially if noted that this entreaty marked his desire for moments of intimacy with the female protagonist, Nola Darling. In her 1995 essay, "The wonderful woman on the pavement: middle-ageism in the postmodern economy," Gullette states, "Economic forces multiply representational forces to make any subject liable to be labeled 'aging'..." With this idea, we can turn to the age identity of the adult consumer. The adult who would purchase this book could be a grandparent who saw the aforementioned film when it first premiered, experienced the 1960s Civil Rights Movement and the consequential cultural shift or all the above. The age identity of the adult consumer could also be that of other adults who ascribe to certain postmodern ideologies of diversity. The age identity of the child listener, reader or beholder is reciprocal in returning us to the meta-discourse revolving around the prescribed norms, ideals and expectations of the socio-cultural environment presented in fiction.

Busy Toes (1998) is a story about a variety of children at different ages and their physical relationships with toes. The age identities of the children in the book are heterogeneous. Clothes, toys, other objects and activities appear in the illustrations as signifiers of childhood. The illustrator's ability to show variation in the children's physicality helps to contrast ages. There is no single child as the main character, rather diverse children are clearly seen in each illustration while the adult remains unseen. Contrary to Rudd's attitudes (2004), Beauvais (2013) is concerned about

\footnotetext{
increasingly threatening derivations of the concept of power: the adult, ..., is 'repressive' (Nodelman, 1994, p. 178), 'colonialist' (Nodelman, 2008, p. 168), 'othering' (Nikolajeva, 2010, passim), 'dominat[ing]' (Knowles and Malmkjær, 1996, p. 44), or creating a 'subservient audience' (Hunt, 1992, p. 6), 'controlled and formed' by didacticism (Lesnik Oberstein, 1994, p. 38)—not to mention Joseph Zornado's (2001) colourfully apocalyptic depiction of adult 'abuse' on children (p. 79).
}

This concern would be completely unwarranted if, however, the global presence of the United Nations' Convention on the Rights of the Child did not find a need to protect children from these kinds of adult influences. These are not the only influences, understandings or realities of adult and child dynamics. Children's literature continues to provide "mirrors, windows and sliding glass doors" (Bishop 1990) to observe societies, people, and behaviors in ideal, realistic and fantastic situations. In Busy Toes (1998), the reader occasionally sees the child's gaze within specific contexts implicating the adult's supervision or assistance. Even the last illustration of the picturebook is suggestive of the 
parental presence with two sets of feet poking out from under the bed covers. Following Joosen's classification, the relationship pattern between the hidden adult and presented child characters can be categorized as that of affinity. The reader can imagine the adult accompanying, encouraging, guiding or leading the textual and non-textual children in this list of toe activities. From this positionality comes the idea "that children's literature does indeed articulate an adult-child relationship marked by power dynamics inside and outside the book; "but that these dynamics are of a sophistication that precludes any easy attribution of "empowerment" or "disempowerment" to one or the other party." (Beauvais 2013, p. 78) A structuralist analysis of Busy Toes to gain psychological insight into the child characters is challenged by the lack of a singular child narrative. Erik Erikson's eight stages of development are shown throughout the book by different child characters from stage one to stage four: (1) the tensions between trust and mistrust, (2) autonomy and doubt, (3) initiation and guilt, and (4) industry versus inferiority. A similar broad stroke can be drawn with Freud's theory of development showing children from the oral stage to latency stage, as well as Piaget's stages of development from sensorimotor to concrete operational. A trusting baby can be seen with its toes in its mouth. The reader can see child toes through ripped socks, splashing puddles and drawing with its toes. The child characters are learning a range of physical and socio-emotional skills through different situational experiences indoors and outdoors that match Vygotsky's theory of the Zone of Proximal Development.

But how and where can we find the counterpoints between childhood and old age as root metaphors? What cultural and social associations are ascribed to feet and toes? In what ways do literal and metaphorical performances of exploration complement those of experience? By now, we should see that the narration of age identity is not only bound to the social and cultural positioning of individuals, but economic, geographic and historical positioning as well. The objective of this study was to highlight how the narration of age in picturebooks can position the characters, readers and consumers both socially and culturally. Familiarity or unfamiliarity with narrative features such as cityscape or landscapes, availability and use of specialist resources, and the subtle culturallybased messaging also position real and fictitious participants of the narrative. Before and into the first part of the twentieth century some children and older adults in America had their feet and toes exposed because they were poor and as such their exposure was a source of shame. I wonder if we could apply this axiom to the interaction of youth and senescence. 
Returning to reader-response transactional theory and engaging in critical content analysis, let's take a moment to focus on the author. C.W. Bowie is a

The objective of this study was to highlight how the narration of age in picturebooks can position the characters, readers and consumers both socially and culturally. Familiarity or unfamiliarity with narrative features such as cityscape or landscapes, availability and use of specialist resources, and the subtle culturallybased messaging also position real and fictitious participants of the narrative. pseudonym for three women writers: Claudine Wirths, Wendie Old and Mary Bowman-Kruhm. Bowman-Kruhm, in addition to being a writer, has been an educator and researcher concerned with social justice. Old, no pun intended with her last name, was a children's librarian, now retired. Wirth, who died in 2000 , was an educator and psychology researcher. One book in particular she wrote with co-author, Richard $\mathrm{H}$. William is Lives through the Years; Styles of Life and Successful Aging (1965) in which the researchers document six successful styles of transition to old age. The creators of Busy Toes (2000) with its multiethnic chalk illustrations, were intentional in the sociocultural positioning of age identities. A major counterpoint between childhood and old age in this work concerns physical abilities, not disabilities. Agency, creativity and joy are derived from being able to control these fine motor movements and celebrate their exposure. The past cultural and social associations ascribed to exposed feet and toes are subverted from being vulnerable, shameful or punitive to redefining their intimacy. This is generational and originates in the counterculture movement of the 1960s. The literal and metaphorical performances of exploration complement those of experience within the text and among its readers. However, for teenagers navigating the liminal space of childhood and adulthood, performativity is ever more complex. There are not any adolescents depicted in the picturebook, nor is there any apparent insinuation of their presence. Some of the expected behaviors, attitudes and activities rely on the absence of and inconsistency of age performances of teenagers. When placed alongside a child they may become the de facto adult or alternatively, in the presence of an adult, they become the child. Justyna Deszcz-Tryhubczak quotes a sixteen-year-old reflecting on the issue of children's rights as saying, "We want to be treated like adults and we don't know why no one treats us like adults, but I realized why I wasn't treated like adult: I really wasn't one'" (p. 215). Hollindale's (1997) understanding of the child includes self-awareness as such: "A child is someone who believes on good grounds that his or her condition of childhood is not yet over" (p. 30). 


\section{Discussion}

The main purpose of this study is to bring attention to how age, specifically childhood, is narrated in modern picturebooks. Connotations found in the intertextuality elucidate why representations of various ethnicities and the dismantlement of gender roles are important. Please, Baby, Please and Busy Toes showed similar ways in which age is narrated and how it locates social and cultural positionings. Both picturebooks resist identifying or addressing any of the children depicted by name. Possible motives could be that authors wanted to avoid gender spectrum focalizations, ethnic tropes or temporal fossilizations of names. I intentionally evade the polarization of power along age narrations in my analysis and gesture toward shared, intergenerational agency and interdependence in and around the narratives. For example, I purposely did not interrogate the power dynamic of the adult narrator in Please, Baby, Please when addressing the child as "baby," instead of using a proper name.

Entanglements of dominance and endearments become convoluted especially when taking into account the narrative influence African American blues music historically has in storytelling and the invocation of "baby" as a common lyrical and emotionally charged element. "Baby" as a term of endearment, an exaltation or a supplication on the part of the narrating adult can point to shared socio-cultural experiences beyond the immediacy of the moment and reinforce sentiments of love, not necessarily in terms of dominance, but interdependence that work within and outside of the picturebook

Entanglements of dominance and endearments

become convoluted especially when taking into account the narrative influence African American blues music historically has in storytelling and the invocation of "baby" as a common lyrical and emotionally charged element. "Baby" as a term of endearment, an exaltation or a supplication on the part of the narrating adult can point to shared socio-cultural experiences beyond the immediacy of the moment and reinforce sentiments of love, not necessarily in terms of dominance, but interdependence that work within and outside of the picturebook. As Janet Evans points out,

This fusion [of music and storytelling] allows the reader/viewer/listener to become deeply immersed in a picturebook whilst at the same time drawing on their personal thoughts and experiences, thus rendering the meaning of the book even more powerful. (p. 47). 
I apply a combination of methods to support the advantages of using two kinds of literary interpretations. Structuralist and postmodernist approaches are complementary tools of analysis. This was particularly useful in analyzing Busy Toes with a postmodern perspective as a way to bring critical attention to the historical social and cultural importance of toes. Karín Lesnik-Oberstein's (Lesnik-Oberstein 2005 p. 17-29) constructivist approach to recognize frameworks, divisions, political and economic forces in which the universality of the existence of the child, childhood and children's literature if at most are elusive, yet ultimately, inexistent or imaginary remain helpful in guiding the inescapable subjectivities of age. Trites (2018) calls for critical attention to distinguish between "literature" and historical "background" which would significantly inform, "the particular cultural meanings codified in particular aesthetic expressions, for formal properties can't be sealed off from their social and historical matrix." (p. 42) Nikolajeva (2019) considers the alternatives of cognitive poetics and evolutionary literary criticism which must take into consideration biological aspects of human existence. Joosen (2018) claims that age is not a biological given, but rather a social performance, that is negotiated and narrated by culture and therefore can be evaluated metaphorically. If childhood and old age can be treated as a root metaphor both objectively and subjectively through what Lakoff and Johnson (1980) identify as reason and imagination, then one can engage age and ethnicity in metaphorical thought. Here is where multiple theoretical structures need to engage in disturbing ongoing historical peculiarities and injustices.

If one evaluates the root metaphor of age and ethnicity, can an interpolation of performative age eradicate ongoing racist sentiments of African Americans being viewed infantile by some and perpetuated in popular narratives? In a similar way, can age and gender be engaged in metaphorical thought to eliminate the bias some have concerning the childishness of women? Or are we to brush off the root metaphorical construct of the child and the woman as one and the same as paternalistic humor? Aetonormativity, a term coined by Nikolajeva (2009), misrepresented, creates lines of thinking that positions the adult as more powerful than the child in the same way male European imperialists are more powerful than certain ethnic groups and women. (Rudd 2004, Beauvais 2013) Without discounting the dynamics of age completely, I do not fully concur that, "Taken together, intersectionality and aetonormativity help us consider the unique forms of oppression that occur in the matrix of age and other forms of difference." (Trites 2018, p. 32) This assertion is empirically flawed with regard to the adult and child's relationship. The child cannot independently survive and thrive without the presence of the adult. Negligence or absence to attend to the child could be in most, if not all situations, legally deemed criminal. This is not a direct parallel for an individual who 
has been systematically disenfranchised based on ethnicity, gender, geography and economic status. The oppressor can be removed along with its structural and systemic machinations of persecution, and the subaltern (Spivak 1988) individual can survive and thrive. Although following this line of research and broadening the debate about root metaphors in action with intersectionalities, a term coined by Kimberle Crenshaw (1989), and aetonormativity would be interesting, doing so is beyond the scope of this study.

\section{Conclusions}

Age narration does not happen in isolation. Age narrations in picturebooks document pre-existing iterations of attitudes, expectations and experiences along the age spectrum that confirm as much as reject or question the socio-cultural positioning of individuals in historical periods, geographic locations and economic structures. The literal and figurative interplay of the child, the adolescent and the adult gently anchor understandings, meanings and experiences of life both in lived and narrated forms. The behaviors and experiences expected from a child are different from the expected behaviors and experiences of an adolescent or an adult. The notions regarding children are contrived historically and geographically as these beliefs evolve over time, yet ethnicity, gender and class fragment into boundaries which some scholars sometimes choose to ignore in an attempt to uphold ideals of Eurocentric capitalist middle-class hegemony. Contrary to fabricating impossible and biased ideals of children and their childhoods, modern publications of children's literature recast these representations of age to coalesce more effectively with the varied realities of children.

Please, Baby, Please and Busy Toes are two examples of picturebooks that narrate childhood experiences through ethnic visualizations, which were previously negated, excluded or misrepresented. These stories are experienced while suspended among interactions of historical periods, geographic locations and economic structures that attempt to bypass gender and indirectly question the hegemony of prevailing views. Children's literature overtly and subliminally sends powerful messages about age, ethnicity and gender and these factors influence one's position in the world at large. Picturebooks are an example of products involved in a network of activity, that commodifies to a certain extent childhood, ethnicity and gender while interacting with the historical understandings and cultural implications each hold. In this study, we observe the agency of the child, the positive representation of ethnicity and the flattening of gender. The two picturebooks served as "mirrors" (deriving the metaphoric terminology from Rudine Sims Bishop) for African American readers, "windows" for readers who engage diversity and "sliding glass doors" for the ageless, 
critical and empathetic reader. (Bishop 1990, Chenoweth 2019). Even though I was able to use the combined methods of structuralist interpretation, critical content analysis, close reading and contextualization for two picturebooks, greater insights may have been possible with the application of digital humanities software. Firstly, computer analysis, in complementing and enriching my observations, may reveal hidden themes, not necessarily detected by me and secondly, a significantly larger corpus could be examined. The implications of this study point to possible applications in the design of age narrations in current and future literacies, especially in the emerging field of digital humanities.

\section{References}

Ariès, P. (1972). Centuries of Childhood. Harmondsworth: Penguin. (cross referenced).

Arizpe, E, Bagelmann, C., Colomer, T., \& Martínez-Roldán, C. (2014). Visual Journeys through Wordless Narratives. London: Bloomsbury Academic.

Beauvais, C. (2013). The Problem of 'Power': Metacritical Implications of Aetonormativity for Children's Literature Research. Children's Literature in Education, (44), 74-86.

Beauvais, C. (2014). Little tweaks and fundamental changes: two aspects of sociopolitical transformation in children's literature. In Keyes, M.T., McGillicuddy, A. (Eds.), Politics and Ideology in Children's Literature (pp. 20-30). Ireland: Four Courts Press.

Bishop, R. S. (1990). Mirrors, windows, and sliding glass doors. Perspectives: Choosing and Using Books for the Classroom, 6, 3, ix-xi.

Bowie, C.W., Wilingham, F. (ill.) (1998). Busy Toes. New York: Scholastic.

Butler, J. (1988). Performative Acts and Gender Constitution: An Essay in Phenomenology and Feminist Theory. Theatre Journal, 40(4), Dec., 519-531.

Carvalho, M.J., \& Nazareth, C. (ill.) (2003). Nuestros Derechos. La Coruña, Spain: Editorial Everest.

Chenoweth, R. (2019, September 9). Rudine Sims Bishop: 'Mother' of multicultural children's literature. Retrieved from https://ehe.osu.edu/news/listing/rudine-sims-bishop-diverse-childrens-books/

Coats, K. (2017). The Bloomsbury Introduction to Children's and Young Adult Literature. USA and UK: Bloomsbury Academic.

Crenshaw, K. (1989). Demarginalizing the Intersection of Race and Sex: A Black Feminist Critique of Antidiscrimination Doctrine, Feminist Theory and Antiracist Politics. University of Chicago Legal Forum. 1989, 1, Article 8.

Deszcz-Tryhubczak, J. (2016). Using Literary Criticism for Children's Rights: Toward a Participatory Research Model of Children's Literature Studies. The Lion and the Unicorn, 40(2), 215-231.

Erikson, E. (1995). Dialogue with Erik Erikson (Master Work). Evans, R.E. (Ed.). New York and London: Harper \& Row.

Evans, J. (2018). Human Rights issues linked to War, Conflict and Peace Reflected in Picturebooks Through Art, Music and Song Lyrics. Journal of Literary Education.,1, 39-57. 
Foer, S. (2005). Extremely Loud and Incredibly Close.

García González, M., Minguez Lopez, X. (under review). Diversity and Homogeneity in Spanish-language Picturebooks with Non-Human Characters. Intercultural Education.

Geertz, C. (1975). The Interpretation of Cultures. New York: Basic Books.

Greenberg, P., Aliki (ill.) (2002). Oh Lord, I Wish I was a Buzzard. New York: Seaside Books.

Gullette, M.M. (1995). The wonderful woman on the pavement: middle-ageism in the postmodern economy. Dissent, (Oct 1), 508-514.

Gullette, M.M. (2004). Aged by Culture. Chicago and London: The University of Chicago Press.

Hendrick, H. (1992). Children and Childhood. Refresh: Recent Findings of Research in Economic and Social History. Autumn, 15, 1-4.

Hollindale, P. (1997). Signs of Childness in Children's Books. United Kingdom: Thimble Press. (cross referenced).

Hunt, P. (Ed). (2009). Understanding Children's Literature. London and New York: Routledge.

Hunt, P., \& Ray, S. (Eds). (2005). International Companion Encyclopedia of Children's Literature. London and New York: Routledge.

Jones, K. (2006). Getting Rid of Children's Literature. The Lion and the Unicorn, 30(3), 287-315.

Joosen, V. (2018). Connecting Childhood and Old Age in Popular Media. Jackson: University Press of Mississippi.

Kumaravadivelu, B. (1992). Macrostrategies for the Second/Foreign Language Teacher. The Modern Language Journal 76 (1), 41-49.

Kumaravadivelu, B. (2003). A Postmethod Perspective on English Language Teaching. World Englishes. $22,4,539-550$.

Lakoff, G., \&Johnson, M. (1980). Metaphors We Live By. Chicago and London: University of Chicago Press.

Lee, S., \& Lewis Lee, T., Nelson, K. (ill.) (2002). Please Baby, Please. New York: Aladdin Paperbacks.

Lesnik-Oberstein, K. (2005). Defining Children's Literature. In P. Hunt \& S. Ray (Eds). International Companion Encyclopedia of Children's Literature (pp. 17-31). London and New York: Routledge.

Mahamud-Angulo, K. (2020). Propuesta Metodológica Multimodal e Interdisciplinar en Investigación Manualistaca. Revista Brasileia de Históris da Educação, 20, 1-25.

Martínez-Roldán, C. (2017). When Entertainment Trumps Social Concerns: The Commodification of Mexican Culture and Language in Skippyjon Jones. In Johnson, H., Mathis, J. \& K. G. Short (Eds). Critical Content Analysis of Children's and Young Adult Literature: Reframing Perspective (pp. 61-76). New York: Routledge.

McAdams, D. P. (1994). The Person: An Introduction to Personality Psychology. Fort Worth: Harcourt Brace College Publishers.

McAdams, D. P. (2008). Personal narratives and the life story. In O. P. John, R. W. Robins, \& L. A. Pervin (Eds.). Handbook of personality: Theory and research (pp. 242-262). New York: The Guilford Press.

Mills, C. (2005). Books for Young Readers. In P. Hunt \& S. Ray (Eds). International Companion Encyclopedia of Children's Literature (pp. 377-386). London and New York: Routledge. 
Mínguez-López, X. (2015). Una definición altamente problemática: la literatura infantil y juvenil y sus ámbitos de estudio. SEDLL. Lenguaje y Textos, (mayo 41), 95-105.

Monreal, V. (2000). ¿Por que estas triste?. La Coruña, Spain: Editorial Everest.

Myers, M. (1988). Missed Opportunities and Critical Malpractice: New Historicism and Children's Literature. Children's Literature Association Quarterly, Spring 13 (1), 41-43.

Nel, P., \& Paul, L. (Eds.). (2011). Keywords for Children's Literature. New York and London: New York University Press.

Nelson, K., \& Fivush, R. (2004). The Emergence of Autobiographical Memory: A Social Cultural Developmental Theory. Psychological Review, 111(2), 486-511.

Nikolajeva, M. (2019). What is it Like to be a Child? Childness in the Age of Neuroscience. Children's Literature in Education, (50), 23-37.

Rivas, M. (Ed.) (1997). Trabajar no es un juego. Madrid and Barcelona: Fundación CEAR, Editorial Debate and Editorial Planeta.

Rosenblatt, L. M. (1994). The Reader, the Text, the Poem: The Transactional Theory of Literary Work. United States: Southern Illinois University.

Rudd, D. (2004). Border crossings: Carrie's War, children's literature and hybridity. English, Film and Media and Creative Writing: Book Chapters. Paper 1. Recovery from http://digitalcommons.bolton.ac.uk/emcs_chapters/

Spivak, G. C. (1988). Can the Subaltern Speak? In C. Nelson \& L. Grossberg, L. (Eds). Marxism and the Interpretation of Culture (pp. 24-28 ). London: Macmillan.

Stearns, P. N. (2006). Childhood In World History. New York: Routledge. (cross referenced).

Sutherland, C. (2009). Critical tradition and ideological positioning. In P. Hunt, (Ed.) Understanding Children's LIterature. New York: Routledge.

Trites, R. (2018). Twenty-First-Century Feminisms in Children's and Adolescent Literature. Jackson: University Press of Mississippi.

United Nations Convention on the Rights of the Child. (1989, November 30). Retrieved from https://www.ohchr.org/en/professionalinterest/pages/crc.aspx.

Vygotsky, L. (1978). Mind in Society: The development of higher psychological processes. Cambridge, MA: Harvard University Press.

Wirth, C., \& William, R.H. (1965). Lives through the Years; Styles of Life and Successful Aging. California: Atherton Press.

Wohlmann, A. (2014). Aged Young Adults: Age Readings of Contemporary American Novels and Films. Bielefeld: Transcript Verlag 
How to cite this paper:

Murray, J. I. (2020). Socio-cultural Positioning of Age Identities in Picturebooks. Journal of Literary Education, (3), pp. 137-159. doi: 10.7203/JLE.3.17415 